\title{
FOOD PRODUCTION AND FOOD CONTROL
}

\author{
By Sir JOHN BOYd ORR, F.R.S., \\ RowetT REsEarch Institute, ABERdeEN
}

$\mathrm{I}^{\mathrm{N}}$ anticipation of the War, the Foods (Defence) Plans Ccmmittee, working in co-operation with the trades concerned, prepared an elaborate scheme of focd control for Great Britain. Excellent though this scheme is in some respects, it is not sufficient to deal with the situation. It does not take account of the fact that, even before the War began, the diet of the poorest third of the population was not up to the standard we now know to be necessary for health. This is the weakest part of the food front. Our food plans should be directed first and foremost to bring the diet of these people up to the standard. If they have sufficient, we need not worry about the rest of the population.

The present system of rationing and price fixing cannot bring about an equal sharing of the available food. Coupons have been issued for $4 \mathrm{oz}$. of butter and $4 \mathrm{oz}$. of bacon per week. Even in peace time, when prices were lower, many families could not afford to purchase these amounts. Consequently, we have people with coupons who cannot purchase the rationed amount because they have not the money, and people with plenty of money to purchase the additional amounts they want, but cannot get them because they have not the additional coupons. This fosters an illicit trade in coupons and food which defeats the object of rationing. If the illicit trade does not develop quickly enough, food remains unsold. As the price rises the amount unsold increases until it becomes necessary to increase the rationed amount, so that those with money can purchase more. It is impossible to have two systems, rationing by price and rationing by amount, operating in the same field without creating anomalies. If rationing is to be efficient and to apply to the whole population, the rationed amount must be within the purchasing power of everybody.

Nor does price fixing necessarily benefit the poor. Maximum prices tend to become the minimum. Some commodities have a wide range of prices. Pooling and price fixing will tend to raise the price of the cheapest qualities, which are those that the poor use. Then again, the poor get a less expensive distributive service than the wellto-do. Prices are likely to be fixed on the higher costs of the more expensive service, and the poor may be forced to pay for a service which they cannot afford and indeed will not get.

* The arguments of the present article are set forth at length, with additional data, in a booklet "Feeding the People in War-Time", to appear shortly (London: Macmillan and Co., Ltd ).
It is worth while reconsidering the food policy of Great Britain. We are only at the beginning of what may be a long, grim struggle. The issue will depend as much upon the powers of endurance and the morale of the civilian population as on the efficiency of the fighting forces. Next to having a cause worth fighting for and worth dying for, the most important factor for morale is food. In the War of 1914-18, we sustained serious reverses without any loss of spirit, but there was a grave danger of war-weariness in the food shortage of 1917. Our food policy should be designed to raise to the highest possible level national health and physical fitness, upon which morale and powers of endurance so largely depend. It must, therefore, be based upon nutritional needs.

We should first ascertain the total needs of the population, and then determine how these can best be met, keeping in view the possibilities of increasing home production and the need for using the minimum amount of shipping space and foreign exchange for food imports.

In the first place, we must provide more protective foods to bring consumption among the whole population up to the level among the wellto-do, which is about the level required for health. Then we must provide more energy-yielding foods to meet increased energy expenditure due to the War. Unemployed men and men in sedentary occupations need only about 2,500 calories per day. Many of these will be drawn into industry or the fighting forces. In the former case their needs will increase to between 3,000 and 3,500 calories, and in the latter case to about 4,000 calories. We must make provision for a total increase of probably between 10 and 20 per cent.

We are thus faced with the problem of increasing our total food supplies at a time when we must economize in shipping space and in foreign exchange ; and if we plan to have the whole population adequately fed, we have the further problem of adjusting prices to purchasing power at a time when the cost of food is rising.

In normal times, about two thirds of the total food supplies of Great Britain are imported. Including feeding stuffs for animals, this takes nearly 20 million tons of shipping per annum. Home production must be increased to the utmost limit and the increase should consist of essential foods which are costly to import in terms of shipping space or foreign exchange. The potato should come first on the list. It is the most 
important crop in war. An acre of potatoes yields twice as much food as an acre of wheat, and it is the safest crop to take out of newly ploughed-up pastures. In the War of 1914-18, the yield of potatoes from old pastures averaged $7 \cdot 1$ tons per acre compared with a pre-War average of $6 \cdot 2$ tons on ordinary potato land. The potato is of special nutritive value; it is our main source of vitamin C. In Great Britain the average consumption is only about $9 \mathrm{oz}$. per head per day, though in some families it is as high as $23 \mathrm{oz}$. In Belgium the average consumption is $19 \mathrm{oz}$. and in Germany it is $16 \mathrm{oz}$. We could, with advantage to national health, increase consumption by at least 50 per cent.

The allotment campaign will lead to an increased consumption of vegetables. It is estimated there are about $3 \frac{1}{2}$ million gardens in Great Britain, and the number of allotments is likely to be brought up to nearly $1 \frac{1}{2}$ million. Out of a total of between 10 and 12 million households in the country, there will thus be nearly 5 million wholly or partially self-supporting in vegetables. If our canning factories are running to full capacity in the summer and autumn, building up a store of preserved vegetables for winter use, and if the distribution of farm-grown vegetables be better organized to reduce the gulf between what the producer gets and the consumer pays, it should be possible to bring consumption of nearly the whole population up to about $6 \mathrm{oz}$. per head per day, the level among the well-to-do.

Milk is the most important protective food. There is already sufficient milk in Great Britain to bring consumption among the poor, at present less than a quarter of a pint per head per day, up to nearly two thirds of a pint. There should be no great difficulty in making milk, which is at present surplus to the liquid market, available on a cash and carry basis at a price within the reach of working-class families with children.

Milk, vegetables and potatoes between them contain all the food constituents necessary for health. If everybody has sufficient of these, there need be no malnutrition. If we have the right agricultural policy we can produce sufficient for the needs of the whole population, without reducing the pre-War output of other foods.

With sufficient of these three protective foods, we could, if we were forced by lack of shipping space or foreign exchange, limit imports to the cheap, easily carried, energy-yielding foods. The following table shows the estimated storage space, energy value, and price of some of the main foods we import.

The import policy of Great Britain is, of course, affected by trade and other considerations. Thus, for example, we shall import food from eastern
Europe, not so much because we need it as to keep it out of the hands of the enemy. Considering only nutritional needs, however, priority in imports should be given to bread and fat, until we have a reserve which puts us beyond the danger of a shortage. In 1914-18 we tried to get a reserve of thirteen weeks' supply, but could not maintain it

\begin{tabular}{|c|c|c|c|}
\hline & $\begin{array}{l}\text { Approx. shipping } \\
\text { space (cu, ft. } \\
\text { per ton) }\end{array}$ & $\begin{array}{c}\text { Approx. energy } \\
\text { value ( } 1,000 \text { cal. } \\
\text { per cu. ft. } \\
\text { shipping space) }\end{array}$ & $\begin{array}{c}\text { Cost of } \\
100,000 \mathrm{cal} .\end{array}$ \\
\hline $\begin{array}{l}\text { Sugar } \\
\text { Wheat } \\
\text { Fats \& tallow } \\
\text { Dried fruits .. } \\
\text { Cheese } \quad . . \\
\text { Frozen beef } . . \\
\text { Eggs in shell.. }\end{array}$ & $\begin{array}{r}45 \\
50 \\
80 \\
50 \\
60 \\
95 \\
120\end{array}$ & $\begin{array}{r}83 \\
56 \\
118 \\
55 \\
56 \\
26 \\
12\end{array}$ & $\begin{array}{l}4 s .6 d . \\
5 s .6 d . \\
8 s .6 d . \\
218 . \\
398 . \\
408 . \\
758 .\end{array}$ \\
\hline
\end{tabular}

at that level. With the uncertainty of the present War, we should have at least a six months' reserve of wheat and fat. Of the other foods, sugar is the cheapest energy supplier in terms both of money and shipping space, and would probably be put next to wheat and fat in the list.

If we had sufficient of these energy-yielding foods, together with sufficient milk, vegetables and potatoes, we might be reduced to a spartan diet, but there would never be any need for us to capitulate owing to food shortage. A sufficient amount of the energy-yielding foods could be imported with less than a third of the pre-War shipping space devoted to food and feeding stuffs.

Though these three protective foods and three energy-yielding foods might well form the basis of a national dietary in war-time, it is not suggested that the diet of any part of the population should be reduced to these. Even if shipping space were reduced to a minimum, we would have, in addition to these, all the other foods we can produce at home, and it is exceedingly unlikely that the shipping position will ever be so bad that we cannot continue to import other foods.

The most difficult problem is not the maintaining of supplies to meet nutritional needs; it is, as it was in peace time, one of bringing a sufficient amount of the right kind of food within the purchasing power of working-class families with children. It has already been decided to subsidize food. It might be advisable to confine the subsidies to the absolutely essential foods and to make it sufficient to bring the price of these within the purchasing power of every family.

To provide for the different physiological needs and for different likes and dislikes, it would be necessary to leave a margin of money for the purchase of other foods. Thus, for example, if milk, vegetables and potatoes, bread, fat (butter or margarine) and sugar are chosen as the essential foods to be subsidized, and, if it were found that, 
say $4 s .6 d$. a week was the amount available for food among the poorest 10 per cent of the population, the price of these basic foods should be fixed so that a sufficient amount of them can be bought for, say, $3 s$., leaving $1 s$. $6 d$. for the purchase of other foods, such as beef, mutton, fish, fruit, and tea and other beverages.

With such a policy it is doubtful whether it would be worth while maintaining a costly and elaborate organization for the detailed control of food. The Government is the wholesale purchaser. It can fix wholesale prices at a level estimated to have the retail price within the purchasing power of everybody. If the wholesale prices are known and wholesale distribution equitable, competition between merchants and shopkeepers, who are dependent upon the goodwill of their customers, will probably be sufficient to prevent any profiteering. Indeed, it has never been suggested that there was any gross profiteering amongst shopkeepers. Speculation and profiteering, in so far as it existed at all, was in large wholesale dealing, which is now under Government control.

The policy would provide a flexible system for adjusting the national dietary to what we can afford in money or in shipping space. The few essential foods chosen to be subsidized and to be provided in such abundance as there would be no need for rationing, would be regarded as the rockbottom diet below which we cannot go with safety.
Consumption of the other foods could be controlled by price. If we wish to economize in shipping and foreign exchange, we can limit consumption by increasing the price. On the other hand, if supplies of some other foods were sufficient, they could be added to the list of 'essential' subsidized foods and so brought within the reach of everybody. It is most probable that at the present time some other foods such as cheese and dried fruits could be added to the list. If the Government controls the wholesale trade, which is the bottle neck of our food supply, it can regulate consumption as seems desirable by regulating wholesale prices.

In the same way, home production can be regulated by price. The farmer produces for profit. He increases or decreases his output of different foods according to the price he thinks he will get. The farmer should be given a guaranteed minimum price calculated to call forth the additional food we need. The guaranteed prices of the different foods should be adjusted to each other in such proportion that the foods would be produced in the proportion we want. The control of production by the regulation of the price offered would enable farmers to devote their land to the crops for which they are most suited. This would utilize the land of Great Britain to better advantage and give a greater increase in production than a system of compulsory ploughing-up according to a fixed ratio, without any guidance as to what additional foods should be grown.

\section{THE SEVERE WINTER OF I939-40}

\section{$\mathrm{T}$} HE frost which began on December 27, 1939, and continued with few intermissions until about February 18, 1940, was the most severe in Great Britain since 1895. December 1939 was cold on the whole, the average temperature of $37.8^{\circ} \mathrm{F}$. at Kew being nearly $4^{\circ} \mathrm{F}$. below the normal ; but apart from a short spell of frost about December 22 it did not approach in severity the latter part of the winter. At the end of the month the minimum at Kew fell to $19^{\circ} \mathrm{F}$., but comparatively mild conditions returned during the first week in January. The main period of frost came between January 10 and 24 , when the mean temperature at Kew was continuously below freezing except for January 12 and fell to $22^{\circ} \mathrm{F}$. on January 20 . Some very low minima were recorded in all parts of England and Scotland: $-5^{\circ} \mathrm{F}$. in the screen at Dalwhinnie, $-6^{\circ} \mathrm{F}$. at Bodiam in south-east England and Ambleside in the north-west, and $-10^{\circ} \mathrm{F}$. at Rhayader, all between January 17 and 21. At Greenwich the lowest minimum was $12^{\circ} \mathrm{F}$, identical with the lowest minimum there in February 1929 and $5^{\circ}$ higher than in February 1895. After a short break the month ended with another cold spell, and the mean temperature at Kew was as low as $31 \cdot 3^{\circ} \mathrm{F}$., compared with a normal of $40.5^{\circ}$. February began cold, but severe weather. was not encountered until February 10, when another week of frost began, with very low temperatures about February 14.

There was not a great deal of snow in Britain, except in the north, but an even more disastrous phenomenon, glazed frost, occurred over the South and West of England on January 27-28. All through the Saturday night and most of Sunday, fine rain fell through a layer of air which was just below $32^{\circ} \mathrm{F}$. The raindrops were cooled below freezing point, but remained liquid until they struck the ground or exposed objects, when they froze instantly into hard clear ice. Twigs and branches of trees, telephone wires and railway tracks were coated several inches thick; one length of telegraph wire in Gloucestershire carried a cylinder of ice $2.4 \mathrm{in}$. in diameter, and weighing 